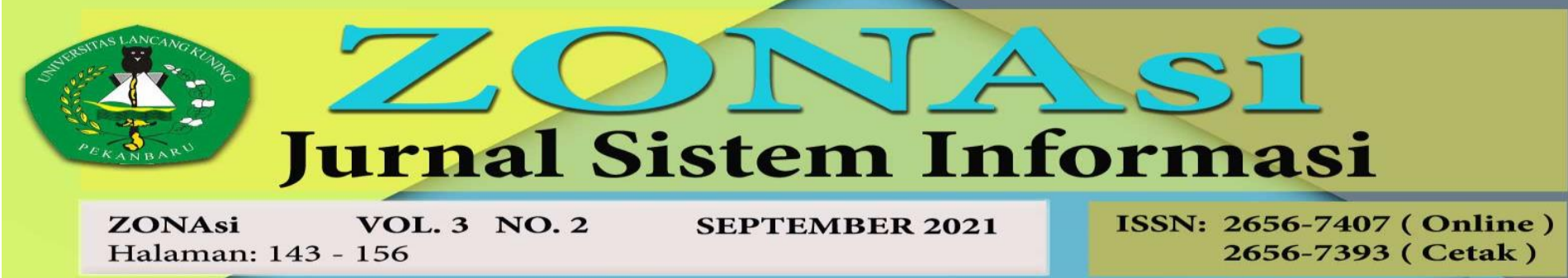

\title{
Analisa Tingkat Kepuasan Masyarakat Terhadap Pelayanan Publik di Polsek Kecamatan Tembilahan
}

\author{
Ahmad Zamsuri ${ }^{1}$, Roki Hardianto ${ }^{2}$, Andre Armada ${ }^{3}$ KeumalaAnggraini $^{4}$ \\ ${ }^{1,2,3}$ Program Studi Teknik Informatika Fakultas Ilmu Komputer Universitas Lancang Kuning \\ J1. Yos Sudarso KM. 8 Rumbai, Pekanbaru, Riau, telp. 08117532015 \\ e-mail: '12ahmadzamsuri@unilak.ac.id, ${ }^{2}$ roki@unilak.ac.id, ${ }^{3}$ andrearmada1203@gmail.com, \\ keumala@unilak.ac.id ${ }^{4}$
}

\begin{abstract}
Abstrak
Kinerja petugas kepolisian adalah tingkat prestasi atau hasil kerja seseorang dari tujuan yang harus dicapai atau dilaksanakan harus sesuai dengan tanggung jawab masing-masing dalam jangka waktu tertentu. Kepuasan kinerja adalah tingkat perasaan seseorang setelah membandingkan kinerja atau hasil yang ia rasakan dibandingkan dengan harapannya. Berdasarkan hasil wawancara masyarakat tentang pelayanan publik di Kantor Kepolisian Sektor Tembilahan, hasilnya menunjukkan kualitas pelayanan yang mereka terima bervariasi. Selain itu tingkat kepuasan masyarakat terhadap pelayanan publik di Kantor Kepolisian Sektor Tembilahan juga berbeda-beda sehingga tingkat kepuasan masyarakat terhadap pelayanan publik di Kantor Kepolisian Sektor Tembilahan tidak dapat disimpulkan. Logika fuzzy menggunakan metode mamdani merupakan salah satu metode untuk menentukan tingkat kepuasan masyarakat terhadap pelayanan publik di Kantor Kepolisian Sektor Tembilahan. Berdasarkan hasil pengujian data yang telah diproses, hasil perhitungan manual adalah 75 sedangkan untuk pengujian sistem menggunakan matlab hasilnya adalah 75. Berdasarkan hasil tes tersebut, dapat disimpulkan bahwa fuzzy logic metode mamdani dapat digunakan untuk menentukan tingkat kepuasan masyarakat terhadap pelayanan publik di Kantor Kepolisian Sektor Tembilahan.
\end{abstract}

Kata kunci: Logika Fuzzy, Metode Mamdani, Matlab, Tingkat Kepuasan Masyarakat

\begin{abstract}
The performance of a police officer is the level of achievement or work of a person from the objectives to be achieved or implemented must be in accordance with their respective responsibilities within a certain period of time. Performance satisfaction is the level of feeling a person feels after comparing the performance or results he or she feels compared to his or her expectations. Based on the results of public interviews about public services at the Tembilahan Sector Police Station, the results showed the quality of services they received varied. Inaddition, the level of public satisfaction with public services in the Tembilahan Sector Police Office also varies so that the level of public satisfaction with public services in the Tembilahan Sector Police Station cannot be concluded. Fuzzy logic using mamdani method is one of the methods to determine the level of public satisfaction with public services in the Tembilahan Sector Police Station. Based on the test results of the data that has been processed, the manual calculation result is 75 while for system testing using matlab the result is 75 . Based on the results of the test, it can be concluded that fuzzy logic mamdani method can be used to determine the level of public satisfaction with public services in the Tembilahan Sector Police Station.
\end{abstract}

Keywords: Fuzzy Logic, Mamdani Method, Matlab, Community Satisfaction Level 


\section{Pendahuluan}

Peran kepolisian dalam suatu negara sangatlah besar untuk suatu pelayanan publik dan bisa juga menjadi alasan terjadinya perubahan kemajuan dalam pemerintahan. Reformasi terhadap pelayanan publik di Indonesia dapat memiliki dampak yang meluas terhadap perubahan aspek- aspek kehidupan pemerintah lainnya sehingga perubahan pada praktek penyelenggaraan pelayanan publik dapat menjadi lokomotif bagi upaya perubahan menuju pemerintahan yang lebih baik lagi. Polsek Tembilahan berada di kecamatan tembilahan kabupaten Indragiri hilir, provinsi riau. Berdasarkan prapenelitian yang telah dilakukan dalam bentuk wawancara terhadap beberapa masyarakat setempat pada hari senin, tanggal 3 Mei 2021. Diperoleh dari sumber pertama bahwa pelayanan publik yang diberikan sudah memuaskan, petugas kepolisian memberikan pelayanan dengan ramah dan sopan. Sumber kedua mengatakan pelayanan publik yang diberikan oleh petugas kepolisian sektor tembilahan kurang memuaskan, sarana dan prasarana seperti ruang tunggu kurang memadai, tidak menjelaskan prosedur pelayanan dengan sederhana, masyarakat diharapkan mandiri untuk hal itu, sehingga membuat masyarakat sulit untuk memahaminya.

Berdasarkan penuturan diatas, terdapat perbedaan tingkat kepuasan masyarakat terhadap pelayanan yang diberikan. maka perlu adanya sebuah metode yang dapat membantu dalam menganalisis ketidakpastian itu, maka dari itu metode fuzzy bisa menjadi salah satu alternatif yang dapat menyelesaikan masalah tersebut. Fuzzy [1] merupakan salah satu metode untuk melakukan analisis sistem yang mendukung ketidakpastian terhadap penilaian manusia. Untuk mempresentasikan hasil logika, fuzzy memiliki beberapa metode yaitu metode mamdani, sugeno, tsukamoto. Metode mamdani merupakan metode yang fleksibel terhadap data yang ada. Kelebihan metode mamdani adalah metode ini lebih dapat diterima oleh banyak pihak dan lebih cocok input yang diterima manusia dan bukan mesin.

Adapun rumusan masalah dalam penelitian ini adalah bagaimana mempresentasikan kepuasan masyarakat terhadap pelayanan yang diberikan kepolisian sektor tembilahan menggunakan logika fuzzy metode mamdani?

Adapun tujuan penelitian yang dilakukan pada kepolisian sektor tembilahan adalah untuk dapat mengukur serta mempresentasikan kepuasan masyarakat terhadap pelayanan publik kepolisian sektor tembilahan. Penelitian ini memiliki karakteristik analisa dan representasi data yang yangbersifat unik. Dimana tidak dapat diperbandingkan dengan lokasi dan waktu penelitian yang sama pada tempat yang berbeda.

Pada penelitian sebelumnya yang berjudul, "Analisa Kepuasan Pelanggan Dalam Layanan Jasa Travel and Tour Pada PT. Denar Pesona Menggunakan Metode Fuzzy.” [2]. Pada penelitian ini menjelaskan bahwa tingkat kepuasan pelanggan dengan metode fuzzy ini, dapat menentukan tingkat kepuasan dan menjadi salah satu solusi untuk meningkatkan efesiensi dan efektifitas proses perubahan dan perbaikan pelayanan di PT. Denar Pesona.

Selanjutnya, pada penelitian dengan judul "Penggunaan Fuzzy Inference System (FIS) Metode Mamdani Untuk Menentukan Kinerja Pelayanan PDAM." [3]. Dalam penelitian ini dapat disimpulkan bahwa penentuan kinerja PDAM menggunakan metode mamdani dengan aspek cakupan pelayanan teknis $(\mathrm{CPT})=4$ (Tinggi), pertumbuhan pelanggan $(\mathrm{PP})=5$ (Sangat Tinggi), tingkat penyelesaian pengaduan $(\mathrm{TPP})=4$ (Tinggi), kualitas air pelanggan $(\mathrm{KAP})=4$, menghasilkan output $=17$ yaitu kinerja pelayanan baik. Dengan menggunakan fuzzy inference system sangat membantu dalam menentukan kinerja pelayanan PDAM.

Penelitian selanjutnya dengan judul "Analisis Kepuasan Pelanggan Travel Menggunakan Metode Fuzzy Service Quality." [4]. Hasil yang didapat dalam penelitian ini yaitu dalam perhitungan defuzzification nilai presepsi tertinggi dari kualitas pelayan sebesar 9,700 dan nilai terendahnya pada fasilitas yang disediakan lengkap dan memadai sebesar 8,812. Sedaangkan indeks kepuasan pelanggan yang didapat sebesar $83,76 \%$, dimana hasil tersebut dapat menjadi motivasi dalam meningkatkan kualitas pelayanan terhadap pelanggan. 
Menurut Ali Ikhwan dkk. analisis adalah sebuah metode untuk mencari solusi dari permasalahan sistem yang ada dengan cara mengelompokkan komponen-komponen yang lebih kecil agar solusi yang ditemukan sesuai dengan kebutuhan sistem. [5]

Logika Fuzzy[6] adalah alat matematika yang kuat untuk mewakili ketidakpastian disegala bidang. Fuzzy secara bahasa diartikan sebagai kabur atau samar samar. Suatu nilai dapat bernilai benar atau salah secara bersamaan. Logika fuzzy pertama kali dikembangkan oleh Prof. Lothfi A. Zadeh, seorang ilmuan Amerika Serikat berkebangsaan Iran dari Universitas California di Barkeley, melalui tulisan pada tahun 1965. Logika fuzzy umumnya diterapkan pada masalah masalah yang mengandung unsur ketidakpastian. Logika fuzzy dikembangkan dari teori himpunan. Di dalam teori himpunan fuzzy, keanggotaan suatu elemen di dalam himpunan dinyatakan dengan derajat keanggotaan yang nilainya terletak di dalam selang $[0,1]$. Logika fuzzy memungkinkan nilai keanggotaan berada di antara 0 atau 1. Artinya, bisa saja suatu keadaan mempunyai dua nilai "ya" dan "tidak", "benar" dan "salah", "baik" dan "buruk" secara bersamaan, namun besar nilainya tergantung pada bobot keanggotaan yang dimilikinya. Logika fuzzy adalah suatu cara yang tepat untuk memetakan suatu ruang input ke dalam suatu ruang output. Secara umum Logika Fuzzy adalah sebuah metodelogi "berhitung" dengan variabel kata kata (linguistic variable), sebagai pengganti menghitung dengan bilangan. [7]

Matlab merupakan salah satu jenis aplikasi yang digunakan untuk memanipulasi matrik, implementasi algoritma, pembuatan antarmuka pengguna dengan program yang menggunakan Bahasa pemrograman beragam. [8]

\section{Metode Penelitian}

Penelitian ini dilakukan di Polsek Kecamatan Tembilahan, dan pelaksanaan penelitian ini dilaksanakan pada bulan Oktober 2020 hingga bulan Juni 2021.

Pada penelitian ini, populasi yang diambil adalah masyarakat yang melakukan pelayanan di Polsek Kecamatan Tembilahan sebanyak 300 orang pertahun. Jumlah ini diperolah dari hasil wawancara yang telah dilakukan kepada Ps. Kasium Kepolisian Sektor tembilahan. peneliti menggunakan rumus slovin untuk menentukan jumlah sample yang akan menjadi target penelitian. Rumus yang digunakan adalah:

$$
n=N /\left(1+N\left(e^{\wedge} 2\right)\right)
$$

Keterangan: $\mathrm{n}=$ jumlah sampel; $\mathrm{N}=$ jumlah populasi; $\mathrm{e}=$ batas tolelir yang digunakan $(8 \%)$

Sehingga jumlah sample yang didapatkan yaitu:

$$
\begin{aligned}
& \mathrm{n}=300 /\left(1+300\left((0.08)^{\wedge} 2\right)\right) \\
& \mathrm{n}=300 /(1+1.92) \\
& \mathrm{n}=300 / 2.92 \\
& \mathrm{n}=102.73, \\
& \mathrm{n}=103 \text { (dibulatkan) }
\end{aligned}
$$

Berdasarkan rumus diatas didapatkan jumlah sample sebanyak 103 responden yang mengisi kuisioner.

Metode yang digunakan dalam penelitian ini adalah fuzzy logic mamdani[9]. Metode ini merupakan salah satu bagian dari fuzzy inference system yang berguna untuk menarik kesimpulan atau suatu keputusan terbaik dalam permasalahan yang tidak pasti. 
Berikut adalah Langkah-langkah dari fuzzy inference system mamdani:

a. Menentukan variabel dan himpunan fuzzy.

b. Menentukan fungsi keanggotaan.

c. melakukan implementasi fungsi implikasi MIN dan komposisi antar rule menggunakan fungsi MAX (menghasilkan himpunan fuzzy baru).

d. Defuzzyfikasi

Input dari proses defuzzyfikasi adalah suatu himpunan fuzzy yang diperoleh dari komposisi aturan-aturan fuzzy. sedangkan output yang dihasilkan merupakan suatu bilangan pada domain himpunan fuzzy tersebut.

\section{Hasil dan Pembahasan}

\subsection{Menentukan variabel dan himpunan fuzzy}

Tabel 3.1.1 Data Variabel dan himpunan fuzzy

\begin{tabular}{|c|c|c|c|c|}
\hline Variabel & $\begin{array}{c}\text { Sub } \\
\text { Variabel }\end{array}$ & Himpunan & Domain & $\begin{array}{r}\text { Semesta } \\
\text { Pembicaraan }\end{array}$ \\
\hline \multirow[t]{16}{*}{ Input } & \multirow[t]{4}{*}{ Pelayanan } & Tidak baik & {$[0-50]$} & \multirow[t]{4}{*}[0-100]{} \\
\hline & & Cukup baik & [40-70] & \\
\hline & & Baik & [60-90] & \\
\hline & & Sangat baik & [80-100] & \\
\hline & \multirow[t]{4}{*}{ Tanggung Jawab } & $\begin{array}{l}\text { Tidak } \\
\text { bertanggung } \\
\text { jawab }\end{array}$ & {$[0-50]$} & \multirow[t]{4}{*}{ [0-100] } \\
\hline & & $\begin{array}{l}\text { Cukup } \\
\text { bertanggung } \\
\text { jawab }\end{array}$ & [40-70] & \\
\hline & & $\begin{array}{l}\text { Bertanggung } \\
\text { jawab }\end{array}$ & [60-90] & \\
\hline & & $\begin{array}{l}\text { Sangat } \\
\text { bertanggung } \\
\text { jawab }\end{array}$ & [80-100] & \\
\hline & \multirow{4}{*}{$\begin{array}{l}\text { Sarana } \\
\text { Prasarana }\end{array}$} & Tidak memadai & {$[0-50]$} & \multirow[t]{4}{*}{ [0-100] } \\
\hline & & Cukup memadai & [40-70] & \\
\hline & & memadai & [60-90] & \\
\hline & & Sangat memadai & [80-100] & \\
\hline & \multirow[t]{4}{*}{ Persepsi } & Tidak baik & {$[0-50]$} & \multirow[t]{4}{*}{ [0-100] } \\
\hline & & Cukup baik & [40-70] & \\
\hline & & Baik & [60-90] & \\
\hline & & Sangat baik & [80-100] & \\
\hline \multirow[t]{4}{*}{ Output } & \multirow{4}{*}{$\begin{array}{l}\text { Tingkat } \\
\text { Kepuasan }\end{array}$} & Tidak puas & {$[0-50]$} & \multirow[t]{4}{*}{ [0-100] } \\
\hline & & Cukup puas & [40-70] & \\
\hline & & Puas & [60-90] & \\
\hline & & Sangat puas & [80-100] & \\
\hline
\end{tabular}

\subsection{Menentukan fungsi keanggotaan}

\subsubsection{Variabel Pelayanan}


Fungsi keanggotaan pada variabel pelayanan adalah sebagai berikut:

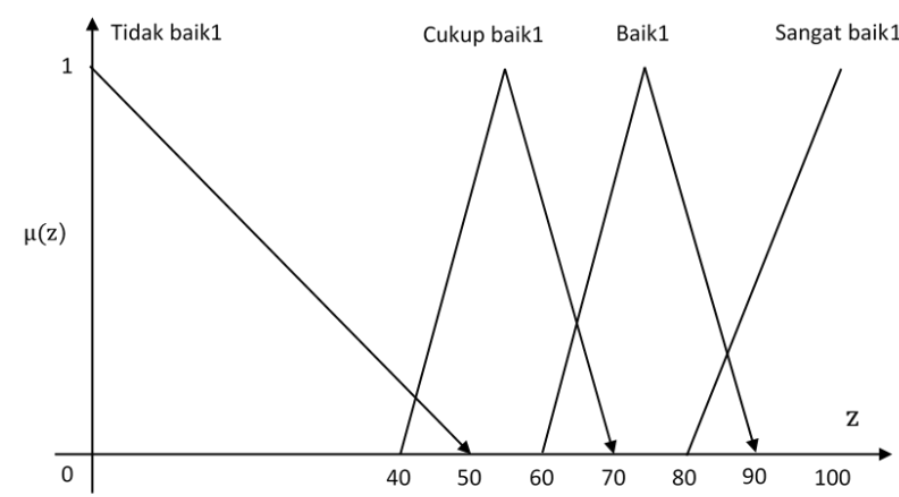

Gambar 3.2.1.1 Grafik keanggotaan variabel pelayanan

Fungsi keanggotaan pada variabel pelayanan dirumuskan sebagai berikut:

$$
\begin{aligned}
& \text { HTidak_baik } 1= \begin{cases}1 & ; x \leq 50 \\
\frac{(60-x)}{(60-40)} & ; 40 \leq x \leq 60 \\
0 & ; x \geq 60\end{cases} \\
& \mu \text { Cukup_baik } 1= \begin{cases}0 & ; x \leq 40 \text { atau } x \geq 70 \\
\frac{(x-40)}{(60-40)} & ; 40 \leq x \leq 60 \\
\frac{(70-x)}{(70-60)} & ; 60 \leq x \leq 70\end{cases} \\
& \mu \text { Baik } 1=\left\{\begin{array}{cl}
0 & ; x \leq 60 \text { atau } x \geq 90 \\
\frac{(x-60)}{(80-60)} & ; 60 \leq x \leq 80 \\
\frac{(90-x)}{(90-80)} & ; 80 \leq x \leq 90
\end{array}\right. \\
& \text { } \mu \text { Sangat_baik } 1= \begin{cases}0 & ; x \leq 80 \\
\frac{(x-80)}{(90-80)} & ; 80 \leq x \leq 90 \\
1 & ; x \geq 90\end{cases}
\end{aligned}
$$

\subsubsection{Variabel Tanggung Jawab}

Fungsi keanggotaan pada variabel tanggung jawab adalah sebagai berikut: 


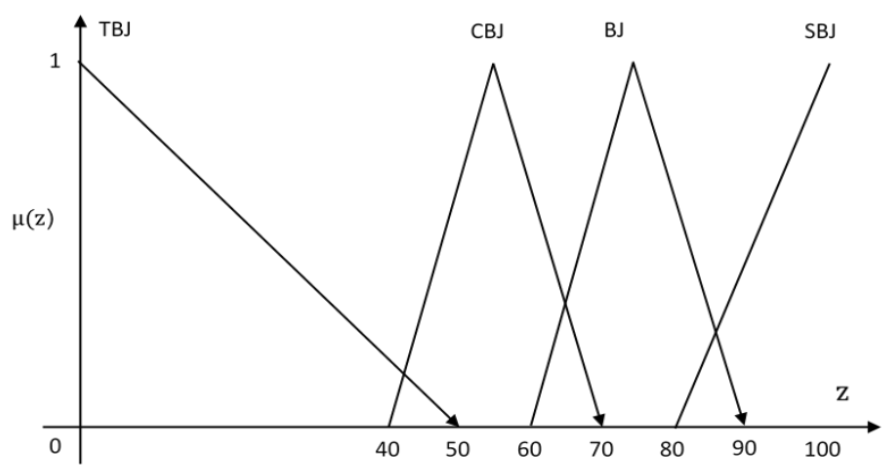

Gambar 3.2.2.1 Grafik keanggotaan variabel tanggung jawab

Fungsi keanggotaan pada variabel tanggung jawab dirumuskan sebagai berikut:

$$
\begin{aligned}
& \mu T B J= \begin{cases}1 & ; x \leq 50 \\
\frac{(60-x)}{(60-40)} & ; 40 \leq x \leq 60 \\
0 & ; x \geq 60\end{cases} \\
& \mu C B J= \begin{cases}\frac{(x-40)}{(60-40)} & ; x \leq 40 \text { atau } x \geq 70 \\
\frac{(70-x)}{(70-60)} & ; 60 \leq x \leq 70\end{cases} \\
& \mu B J=\left\{\begin{array}{cc}
\frac{(x-60)}{(80-60)} & ; x \leq 60 \text { atau } x \geq 90 \\
\frac{(90-x)}{(90-80)} & ; 60 \leq x \leq 80
\end{array}\right. \\
& \mu S B J= \begin{cases}\frac{(x-80)}{(90-80)} & ; 80 \leq x \leq 90 \\
1 & ; x \geq 90\end{cases}
\end{aligned}
$$

\subsubsection{Variabel Sarana Parasana}

Fungsi keanggotaan pada variabel sarana parasana adalah sebagai berikut:

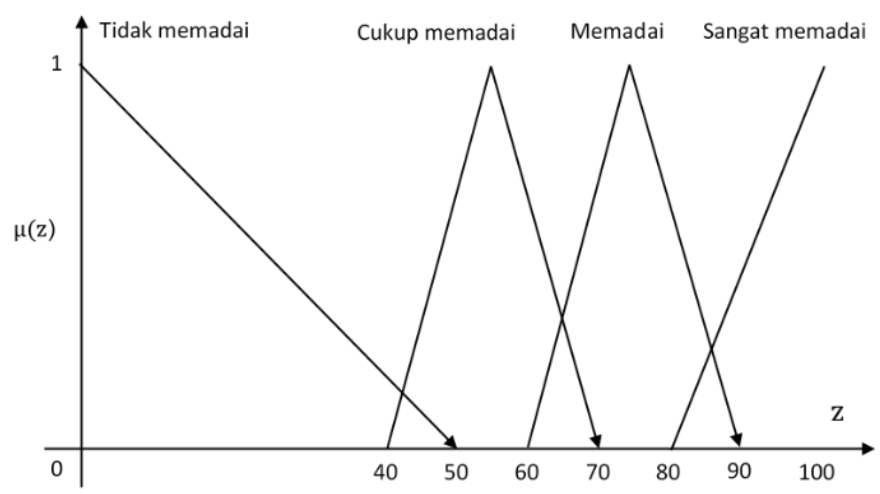


Gambar 3.2.3.1 Grafik keanggotaan variabel sarana parasana

Fungsi keanggotaan pada variabel sarana parasana dirumuskan sebagai berikut:

$$
\begin{aligned}
& \mu \text { Tidak_memadai }= \begin{cases}1 & ; x \leq 50 \\
\frac{(60-x)}{(60-40)} & ; 40 \leq x \leq 60 \\
0 & ; x \geq 60\end{cases} \\
& \mu \text { Cukup_memadai }= \begin{cases}0 & ; x \leq 40 \text { atau } x \geq 70 \\
\frac{(x-40)}{(60-40)} & ; 40 \leq x \leq 60 \\
\frac{(70-x)}{(70-60)} & ; 60 \leq x \leq 70\end{cases} \\
& \text { нMemadai }= \begin{cases}0 & ; x \leq 60 \text { atau } x \geq 90 \\
\frac{(x-60)}{(80-60)} & ; 60 \leq x \leq 80 \\
\frac{(90-x)}{(90-80)} & ; 80 \leq x \leq 90\end{cases} \\
& \mu \text { Sangat_memadai }= \begin{cases}0 & ; x \leq 80 \\
\frac{(x-80)}{(90-80)} & ; 80 \leq x \leq 90 \\
1 & ; x \geq 90\end{cases}
\end{aligned}
$$

\subsubsection{Variabel Persepsi}

Fungsi keanggotaan pada variabel persepsi adalah sebagai berikut:

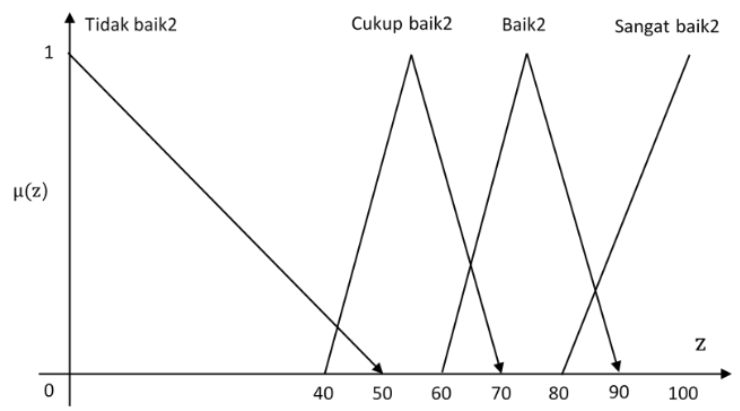

Gambar 3.2.4.1 Grafik keanggotaan variabel persepsi

Fungsi keanggotaan pada variabel persepsi dirumuskan sebagai berikut:

$$
\text { HTidak_baik } 2= \begin{cases}1 & ; x \leq 50 \\ \frac{(60-x)}{(60-40)} & ; 40 \leq x \leq 60 \\ 0 & ; x \geq 60\end{cases}
$$




$$
\begin{aligned}
& \text { } \text { CUkup_baik2 }= \begin{cases}0 & ; x \leq 40 \text { atau } x \geq 70 \\
\frac{(x-40)}{(60-40)} & ; 40 \leq x \leq 60 \\
\frac{(70-x)}{(70-60)} & ; 60 \leq x \leq 70\end{cases} \\
& \mu \text { Baik } 2=\left\{\begin{array}{cl}
0 & ; x \leq 60 \text { atau } x \geq 90 \\
\frac{(x-60)}{(80-60)} & ; 60 \leq x \leq 80 \\
\frac{(90-x)}{(90-80)} & ; 80 \leq x \leq 90
\end{array}\right. \\
& \mu \text { Sangat_baik } 2= \begin{cases}0 & ; x \leq 80 \\
\frac{(x-80)}{(90-80)} & ; 80 \leq x \leq 90 \\
1 & ; x \geq 90\end{cases}
\end{aligned}
$$

\subsection{Melakukan implementasi fungsi implikasi MIN dan komposisi antar rule} menggunakan fungsi MAX.

3.3.1 Melakukan implementasi fungsi implikasi MIN

Fungsi implikasi yang digunakan adalah Min. secara umum dapat dituliskan:

\section{$\mu A \cap B=\min \left(\mu \_A[x]\right),\left(\mu \_B[x]\right)$}

[R1] If (Pelayanan is Tidak_Baik) AND (Tanggung Jawab is TBJ) AND (Sarana\&Prasarana is Tidak_Memadai) AND (Persepsi is Tidak_Baik) THEN (Tingkat Kepuasan is Tidak_Puas)

a-Predikat $1=\mu$ PnTidakbaik $\cap \mu$ TjTBJ $\cap \mu$ SPTidakMemadai $\cap \mu$ PsTidakbaik $=\min (\mu \operatorname{PnTidakbaik}(81), \mu \operatorname{Tj} \operatorname{TBJ}(79.75), \mu \operatorname{SPTidakMemadai}(72), \mu \operatorname{PsTidakbaik}(80)$

$=\min (0 ; 0 ; 0 ; 0)$

$=0$

[R2] If (Pelayanan is Tidak_Baik) AND (Tanggung Jawab is CBJ) AND (Sarana\&Prasarana is Cukup_Memadai) AND (Persepsi is Cukup_Baik) THEN (Tingkat Kepuasan is Cukup_Puas)

aPredikat2 $=\mu$ PnTidakbaik $\cap \mu \mathrm{TjCBJ} \cap \mu$ SPCukupMemadai $\cap \mu$ PsCukupbaik

$=\min (\mu \operatorname{PnTidakbaik}(81), \mu \mathrm{TjCBJ}(79.75), \mu$ SPCukupMemadai(72), $\mu$ PsCukupbaik(80)

$=\min (0 ; 0 ; 0 ; 0)$

$=0$

[R3] If (Pelayanan is Tidak_Baik) AND (Tanggung Jawab is BJ) AND (Sarana\&Prasarana is Memadai) AND (Persepsi is Baik) THEN (Tingkat Kepuasan is Puas)

aPredikat $3=\mu$ PnTidakbaik $\cap \mu \mathrm{TjBJ} \cap \mu \mathrm{SPMemadai} \cap \mu \mathrm{PsBaik}$

$=\min (\mu \operatorname{PnTidakbaik}(81), \mu \mathrm{TjBJ}(79.75), \mu \operatorname{SPMemadai}(72), \mu \operatorname{PsBaik}(80)$

$=\min (0 ; 0.987 ; 0.6 ; 1)$

$=0$

[R4] If (Pelayanan is Tidak_Baik) AND (Tanggung Jawab is SBJ) AND (Sarana\&Prasarana is Sangat_Memadai) AND (Persepsi is Sanga_tBaik) THEN (Tingkat Kepuasan is Sangat_Puas)

aPredikat4 $=\mu$ PnTidakbaik $\cap \mu \mathrm{TjSBJ} \cap \mu$ SPSangatMemadai $\cap \mu P s$ Sangatbaik 
$=\min (\mu \operatorname{PnTidakbaik}(81), \mu \mathrm{TjSBJ}(79.75), \mu$ SPSangatMemadai(72), $\mu$ PsSangatbaik(80)

$=\min (0 ; 0 ; 0 ; 0)$

$=0$

R5] If (Pelayanan is Tidak_Baik) AND (Tanggung Jawab is BJ) AND (Sarana\&Prasarana is Sangat_Memadai) AND (Persepsi is Sangat_Baik) THEN (Tingkat Kepuasan is Sangat_Puas)

aPredikat $5=\mu$ PnTidakbaik $\cap \mu \mathrm{TjBJ} \cap \mu$ SPSangatMemadai $\cap \mu P s$ Sangatbaik

$=\min (\mu \operatorname{PnTidakbaik}(81), \mu \mathrm{TjBJ}(79.75), \mu \operatorname{SPS}$ SangatMemadai(72), $\mu$ PsSangatbaik(80)

$=\min (0 ; 0.987 ; 0 ; 0)$

$=0$

[R6] If (Pelayanan is Cukup_Baik) AND (Tanggung Jawab is TBJ) AND (Sarana\&Prasarana is Tidak_Memadai) AND (Persepsi is Tidak_Baik) THEN (Tingkat Kepuasan is Tidak_Puas)

aPredikat6 $=\mu$ PnCukupbaik $\cap \mu \mathrm{TjTBJ} \cap \mu$ SPTidakMemadai $\cap \mu P s T i d a k b a i k$

$=\min (\mu \operatorname{PnCukupbaik}(81), \mu \mathrm{Tj} \operatorname{TBJ}(79.75), \mu$ SPTidakMemadai(72), $\mu$ PsTidakbaik(80)

$=\min (0 ; 0 ; 0 ; 0)$

$=0$

[R7] If (Pelayanan is Cukup_Baik) AND (Tanggung Jawab is CBJ) AND (Sarana\&Prasarana is Cukup_Memadai) AND (Persepsi is Cukup_Baik) THEN (Tingkat Kepuasan is Cukup_Puas)

aPredikat7 $=\mu$ PnCukupbaik $\cap \mu \mathrm{TjCBJ} \cap \mu$ SPCukupMemadai $\cap \mu$ PsCukupbaik

$=\min (\mu$ PnCukupbaik(81), $\mu \mathrm{TjCBJ}(79.75), \mu$ SPCukupMemadai(72), $\mu$ PsCukupbaik(80)

$=\min (0 ; 0 ; 0 ; 0)$

$=0$

[R8] If (Pelayanan is Cukup_Baik) AND (Tanggung Jawab is BJ) AND (Sarana\&Prasarana is Memadai) AND (Persepsi is Baik) THEN (Tingkat Kepuasan is Puas)

aPredikat $8=\mu$ PnCukupbaik $\cap \mu \mathrm{TjBJ} \cap \mu \mathrm{SPMemadai \cap} \mu \mathrm{PsBaik}$

$=\min (\mu$ PnCukupbaik(81), $\mu \mathrm{TjBJ}(79.75), \mu \operatorname{SPMemadai}(72), \mu \operatorname{PsBaik}(80))$

$=\min (0 ; 0 ; 0 ; 0)$

$=0$

[R9] If (Pelayanan is Cukup_Baik) AND (Tanggung Jawab is SBJ) AND (Sarana\&Prasarana is Sangat_Memadai) AND (Persepsi is Sangat_Baik) THEN (Tingkat Kepuasan is Sangat_Puas)

aPredikat $9=\mu$ PnCukupbaik $\cap \mu \mathrm{Tj}$ SBJ $\cap \mu$ SPSangatMemadai $\cap \mu$ PsSangatbaik

$=\min (\mu$ PnCukupbaik(81), $\mu \mathrm{TjSBJ}(79.75), \mu$ SPSangatMemadai(72), $\mu$ PsSangatbaik(80)

$=\min (0 ; 0 ; 0 ; 0)$

$=0$

[R10] If (Pelayanan is Cukup_Baik) AND (Tanggung Jawab is BJ) AND (Sarana\&Prasarana is Sangat_Memadai) AND (Persepsi is Sangat_Baik) THEN (Tingkat Kepuasan is Sangat_Puas)

aPredikat $10=\mu$ PnCukupbaik $\cap \mu \mathrm{TjBJ} \cap \mu$ SPTidakSangatMemadai $\cap \mu P s S a n g a t b a i k$

$=\min (\mu$ PnTidakbaik(81), $\mu$ TjTBJ(79.75), $\mu$ SPTidakMemadai(72), $\mu$ PsTidakbaik(80)

$=\min (0 ; 0.987 ; 0 ; 0)$

$=0$

[R11] If (Pelayanan is Baik) AND (Tanggung Jawab is TBJ) AND (Sarana\&Prasarana is Tidak_Memadai) AND (Persepsi is Tidak_Baik) THEN (Tingkat Kepuasan is Tidak_Puas)

aPredikat1 $1=\mu$ PnBaik $\cap \mu$ TjTBJ $\cap \mu$ SPTidakMemadai $\cap \mu$ PsTidakbaik

$=\min (\mu$ PnTidakbaik(81), $\mu$ TjTBJ(79.75), $\mu$ SPTidakMemadai(72), $\mu$ PsTidakbaik(80)

$=\min (0.9 ; 0 ; 0 ; 0)$ 
$=0$

[R12] If (Pelayanan is Baik) AND (Tanggung Jawab is CBJ) AND (Sarana\&Prasarana is Cukup_Memadai) AND (Persepsi is Cukup_Baik) THEN (Tingkat Kepuasan is Cukup_Puas)

aPredikat $12=\mu$ PnBaik $\cap \mu \mathrm{TjCBJ} \cap \mu$ SPCukupMemadai $\cap \mu \mathrm{PsCukupbaik}$

$=\min (\mu \operatorname{PnBaik}(81), \mu \mathrm{Tj} \mathrm{CBJ}(79.75), \mu \mathrm{SPCukupMemadai(72), \mu PsCukupbaik(80)}$

$=\min (0.9 ; 0 ; 0 ; 0)$

$=0$

[R13] If (Pelayanan is Baik) AND (Tanggung Jawab is BJ) AND (Sarana\&Prasarana is Memadai) AND (Persepsi is Baik) THEN (Tingkat Kepuasan is Puas)

aPredikat13 $=\mu$ PnBaik $\cap \mu \mathrm{TjBJ} \cap \mu$ SPMemadai $\cap \mu \mathrm{PsBaik}$

$=\min (\mu \operatorname{PnBaik}(81), \mu \mathrm{TjBJ}(79.75), \mu \operatorname{SPMemadai}(72), \mu \operatorname{PsBaik}(80)$

$=\min (0.9 ; 0.987 ; 0.6 ; 1)$

$=0.6$

[R14] If (Pelayanan is Baik) AND (Tanggung Jawab is SBJ) AND (Sarana\&Prasarana is Sangat_Memadai) AND (Persepsi is Sangat_Baik) THEN (Tingkat Kepuasan is Sangat_Puas)

aPredikat14 $=\mu$ PnBaik $\cap \mu \mathrm{TjSBJ} \cap \mu$ SPSangatMemadai $\cap \mu \mathrm{PsSangatBaik}$

$=\min (\mu \operatorname{PnBaik}(81), \mu \mathrm{TjSBJ}(79.75), \mu \operatorname{SPS} a n g a t M e m a d a i(72), \mu \operatorname{PsSangatBaik}(80)$

$=\min (0.9 ; 0 ; 0 ; 0)$

$=0$

[R15] If (Pelayanan is Baik) AND (Tanggung Jawab is BJ) AND (Sarana\&Prasarana is Sangat_Memadai) AND (Persepsi is Sangat_Baik) THEN (Tingkat Kepuasan is Sangat_Puas)

aPredikat15= $\mu$ PnBaik $\cap \mu \mathrm{TjBJ} \cap \mu$ SPSangatMemadai $\cap \mu$ PsSangatBaik

$=\min (\mu \operatorname{PnBaik}(81), \mu \mathrm{TjBJ}(79.75), \mu \operatorname{SPS}$ angatMemadai(72), $\mu \operatorname{PsSangatBaik}(80)$

$=\min (0.9 ; 0.987 ; 0 ; 0)$

$=0$

[R16] If (Pelayanan is Sangat_Baik) AND (Tanggung Jawab is TBJ) AND (Sarana\&Prasarana is Tidak_Memadai) AND (Persepsi is Tidak_Baik) THEN (Tingkat Kepuasan is Tidak_Puas)

aPredikat $16=\mu$ PnSangatBaik $\cap \mu \mathrm{Tj}$ TBJ $\cap \mu$ SPTidakMemadai $\cap \mu$ PsTidakBaik

$=\min (\mu$ PnSangatBaik(81), $\mu$ TjTBJ(79.75), $\mu$ SPTidakMemadai(72), $\mu$ PsTidakBaik(80)

$=\min (0.1 ; 0 ; 0 ; 0)$

$=0$

[R17] If (Pelayanan is Sangat_Baik) AND (Tanggung Jawab is CBJ) AND (Sarana\&Prasarana is Cukup_Memadai) AND (Persepsi is Cukup_Baik) THEN (Tingkat Kepuasan is Cukup_Puas)

aPredikat1 $7=\mu$ PnSangatBaik $\cap \mu \mathrm{TjCBJ} \cap \mu$ SPCukupMemadai $\cap \mu$ PsCukupBaik

$=\min (\mu$ PnSangatBaik(81), $\mu \mathrm{TjCBJ}(79.75), \mu$ SPCukupMemadai(72), $\mu$ PsCukupBaik(80)

$=\min (0.1 ; 0 ; 0 ; 0)$

$=0$

[R18] If (Pelayanan is Sangat_Baik) AND (Tanggung Jawab is BJ) AND (Sarana\&Prasarana is Memadai) AND (Persepsi is Baik) THEN (Tingkat Kepuasan is Puas)

aPredikat $18=\mu$ PnSangatBaik $\cap \mu \mathrm{TjBJ} \cap \mu$ SPMemadai $\cap \mu P s B a i k$

$=\min (\mu \operatorname{PnSangatBaik}(81), \mu \mathrm{TjBJ}(79.75), \mu \operatorname{SPMemadai}(72), \mu \operatorname{PsBaik}(80)$

$=\min (0.1 ; 0.987 ; 0.6 ; 1)$

$=0.1$ 
[R19] If (Pelayanan is Sangat_Baik) AND (Tanggung Jawab is SBJ) AND (Sarana\&Prasarana is Sangat_Memadai) AND (Persepsi is Sangat_Baik) THEN (Tingkat Kepuasan is Sangat_Puas)

aPredikat19 $=\mu$ PnSangatBaik $\cap \mu \mathrm{Tj}$ SBJ $\cap \mu$ SPSangatMemadai $\cap \mu$ PsSangatBaik $=\min (\mu \operatorname{PnSangatBaik}(81), \mu \mathrm{Tj} \operatorname{SBJ}(79.75), \mu$ SPSangatMemadai(72),$\mu$ PsSangatBaik(80)

$=\min (0.1 ; 0 ; 0 ; 0)$

$=0$

[R20] If (Pelayanan is Sangat_Baik) AND (Tanggung Jawab is BJ) AND (Sarana\&Prasarana is Sangat_Memadai) AND (Persepsi is Sangat_Baik) THEN (Tingkat Kepuasan is Sangat_Puas)

aPredikat20 $=\mu$ PnSangatBaik $\cap \mu \mathrm{Tj} \mathrm{BJ} \cap \mu$ SPSangatMemadai $\cap \mu P s$ SangatBaik $=\min (\mu$ PnSangatBaik $(81), \mu \mathrm{TjBJ}(79.75), \mu$ SPSangatMemadai(72), $\mu$ PsSangatBaik(80) $=\min (0.1 ; 0.987 ; 0 ; 0)$ $=0$

Tabel 3.3.1.1 Hasil perhitungan fungsi implikasi min dari rule 1-20

\begin{tabular}{|c|c|c|c|c|}
\hline Himpunan & Tidak Puas & Cukup Puas & Puas & Sangat Puas \\
\hline \multirow{20}{*}{$\begin{array}{c}\text { Hasil } \\
\text { perhitungan } \\
\text { fungsi implikasi } \\
\text { min }\end{array}$} & {$[R 1]=0$} & & & \\
\hline & & {$[R 2]=0$} & & \\
\hline & & & $3]=0$ & \\
\hline & & & & {$[R 4]=0$} \\
\hline & & & & {$[R 5]=0$} \\
\hline & {$[R 6]=0$} & & & \\
\hline & & {$[R 7]=0$} & & \\
\hline & & & $R 8]=$ & \\
\hline & & & & {$[R 9]=0$} \\
\hline & & & & {$[R 10]=0$} \\
\hline & {$[R 11]=0$} & & & \\
\hline & & {$[R 12]=0$} & & \\
\hline & & & 13] $=$ & \\
\hline & & & & {$[R 14]=0$} \\
\hline & & & & {$[R 15]=0$} \\
\hline & {$[R 16]=0$} & & & \\
\hline & & {$[R 17]=0$} & & \\
\hline & & & 18] $=$ & \\
\hline & & & & {$[R 19]=0$} \\
\hline & & & & {$[R 20]=0$} \\
\hline
\end{tabular}

3.3.2 Komposisi antar rule menggunakan fungsi max

Tabel 3.3.2.1 Hasil perhitungan fungsi komposisi fungsi max

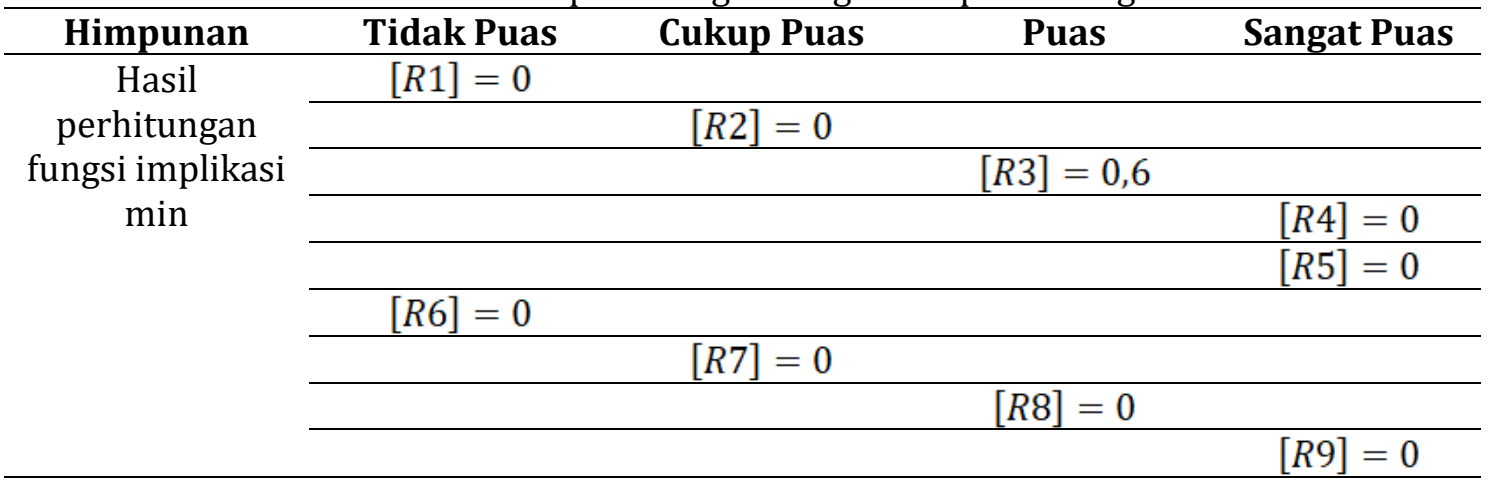




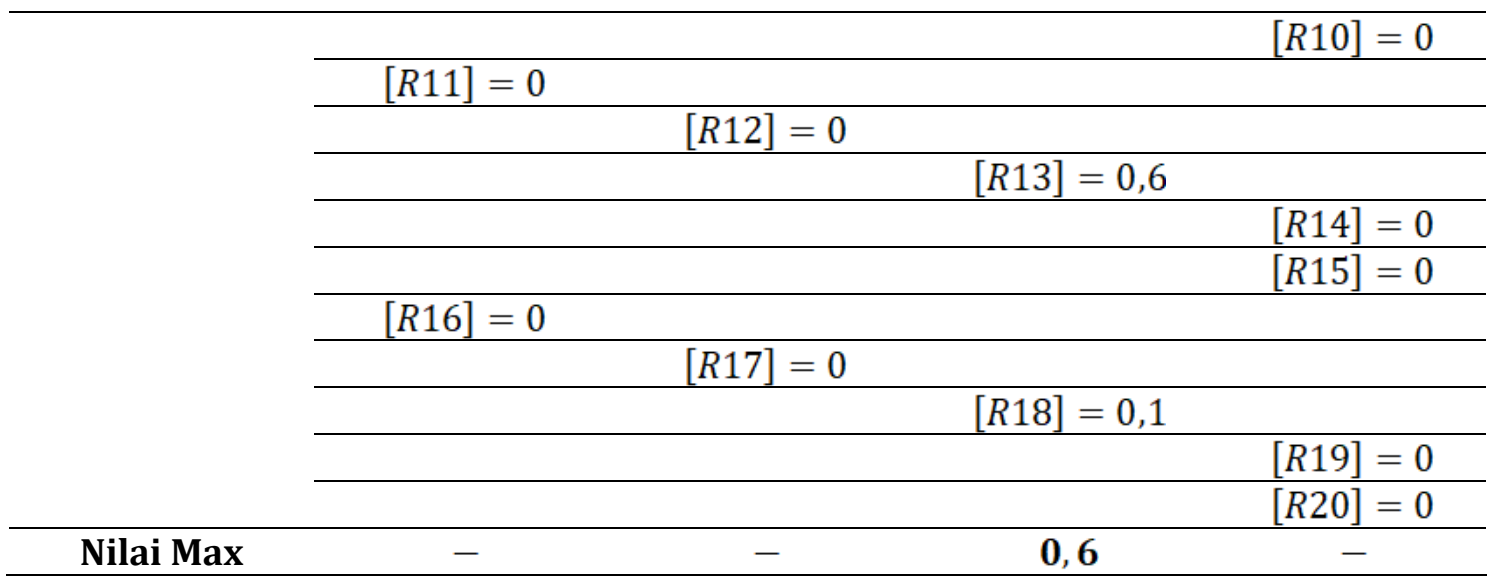

\subsection{Deffuzyfikasi}

Tahap ini disebut juga tahap penegasan. Input dari proses penegasan ini adalah suatu himpunan kabur yang diperoleh dari komposisi aturan-aturan kabur, sedangkan output yang dihasilkan merupakan suatu bilangan pada domain himpunan kabur tersebut. Dalam tahap ini peneliti menggunakan centroid method. Metode ini disebut juga sebagai Center of Area atau Center of Gravity. Metode ini menghitung nilai crisp menggunakan rumus:

$$
z=\frac{\int \mu(z) z d z}{\int \mu(z) d z}=\frac{\operatorname{Momen}(M)}{\operatorname{Luas}(A)}
$$

Gambar 3.4.1 Grafik daerah yang diperoleh dari aturan komposisi

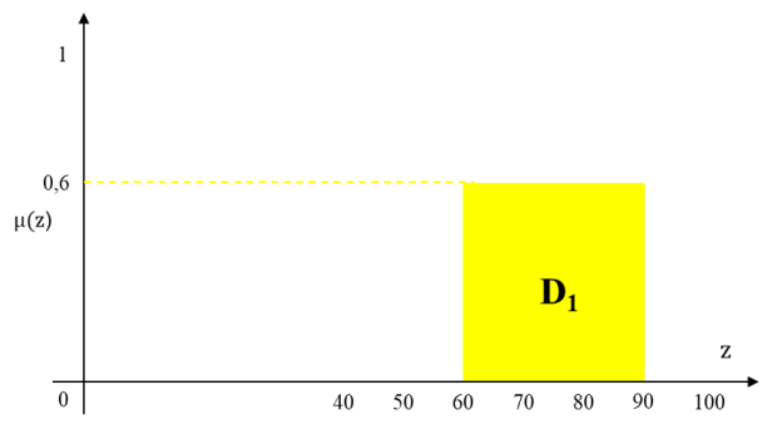

Gambar 3.4.1 Grafik daerah yang diperoleh dari aturan komposisi

$$
\begin{aligned}
& z=\frac{\operatorname{Momen}(M)}{\operatorname{Luas}(A)} \\
& M=\int \mu(z) z d z \\
& M=\int_{60}^{90} \mu 0,6 z d z=\left[0,6 * \frac{1}{2} z^{2}\right]_{60}^{90} \\
& =(0,3 * 8100)-(0,3 * 3600)=(2430-1080)=1350 \\
& A=\int \mu(z) d z
\end{aligned}
$$




$$
\begin{aligned}
& A=\int_{60}^{90} 0,6 d z=(90-60) * 0,6=18 \\
& Z=\frac{1350}{18}=75
\end{aligned}
$$

Jadi hasil defuzzyfikasi bernilai 75 dan termasuk ke dalam himpunan "PUAS"

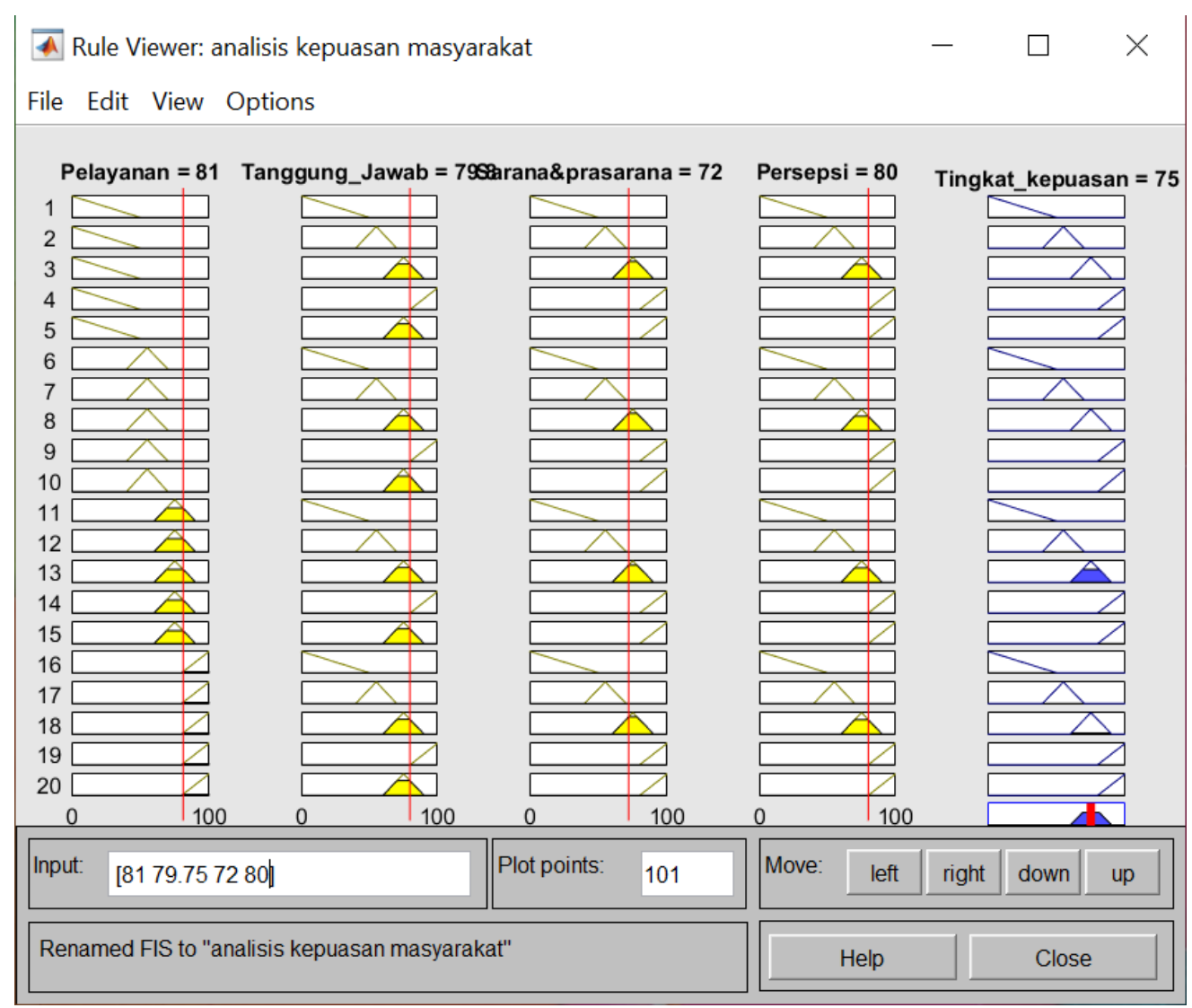

Gambar 3.4.2 Hasil tingkat kepuasan menggunakan toolbox fuzzy matlab

Pada Gambar 3.4.2 dapat dilihat hasil yang diperoleh menggunakan Matlab R2020a. Hasil dari penegasan diperoleh sebagai berikut:

a. Input, meliputi:

1. Pelayanan, didapatkan bilangan real sebesar 81 , yaitu merupakan keanggotaan dari domain pelayanan himpunan baik1.

2. Tanggung Jawab, didapatkan bilangan real sebesar 79.75, yaitu merupakan keanggotaan dari domain tanggung jawab himpunan bertanggung jawab.

3. Sarana dan Prasarana, didapatkan bilangan real sebesar 72, yaitu merupakan keanggotaan dari domain sarana dan prasarana himpunan memadai.

4. Persepsi, didapatkan bilangan real sebesar 80 , yaitu merupakan keanggotaan dari domain persepsi himpunan baik2.

b. Output tingkat kepuasan didapatkan bilangan real sebesar 75 yaitu merupakan keanggotaan dari domain tingkat kepuasan himpunan puas yang artinya variabel tingkat 
kepuasan dikatakan puas yaitu 75. Berdasarkan hasil yang diperoleh dengan menggunakan perhitungan fuzzy mamdani secara manual maupun dengan Matlab R2020a, terlihat bahwa hasil menyatakan kepuasan masyarakat dengan nilai yang sama dari hitung manual 75 dengan Matlab R2020a 75 dan dinyatakan puas.

\section{Kesimpulan}

4.1. Didapatkan bilangan real pada variabel pelayanan sebesar 81, variabel tanggung jawab sebesar 79,75. variabel sarana \& prasarana sebesar 72, dan variabel persepsi sebesar 80.

4.2. Hasil Analisa tingkat kepuasan masyarakat terhadap pelayanan publik di kantor Kepolisian Sektor Tembilahan menggunakan hitung manual sama dengan pengujian pada fuzzy toolbox Matlab adalah sebesar 75 dan nilai tersebut termasuk ke dalam himpunan "PUAS".

\section{Daftar Pustaka}

[1] "Fuzzy Sets \& Fuzzy Logic -- Theory \& Applications [Klir \& Yuan].pdf." 1995.

[2] N. Iriadi, P. Priatno, and P. A. Sulistia, "Analisa Kepuasaan Pelanggan dalam Layanan Jasa Travel and Tour pada PT. Denar Pesona Menggunakan Metode Fuzzy Servqual," MATRIK J. Manajemen, Tek. Inform. dan Rekayasa Komput., vol. 18, no. 2, pp. 192201, 2019, doi: 10.30812/matrik.v18i2.371.

[3] A. Puspitasari, "Penggunaan Fuzzy Inference System ( Fis ) Metode Mamdani Untuk Menentukan Kinerja Pelayanan Pdam," J. Tek. Komput. AMIK BSI, vol. III, no. 1, pp. 51-59, 2017.

[4] H. Sholikah and S. W. Iriananda, "Analisis Kepuasan Pelanggan Travel Menggunakan Metode Fuzzy Service Quality," JOINTECS (Journal Inf. Technol. Comput. Sci., vol. 2, no. 2, 2017, doi: 10.31328/jointecs.v2i2.468.

[5] A. Ikhwan, M. Badri, M. Andriani, and N. Saragih, "Analisis Tingkat Kepuasan Pelanggan Menggunakan Fuzzy Mamdani ( Studi Kasus : Busrain Bakery ),” vol. 18, no. 2, pp. 147-153, 2019.

[6] M. A. Adiguna and A. Muhajirin, "Penerapan Logika Fuzzy Pada Penilaian Mutu Dosen Terhadap Tri Dharma Perguruan Tinggi," J. Online Inform., vol. 2, no. 1, p. 16, 2017, doi: 10.15575/join.v2i1.74.

[7] M. Y. T. Irsan, M. I. Kasau, and I. P. Simbolon, "Penggunaan Fuzzy Logic \& Metode Mamdani untuk Menghitung Pembelian, Penjualan dan Persediaan," JAAF (Journal Appl. Account. Financ., vol. 3, no. 1, p. 37, 2019, doi: 10.33021/jaaf.v3i1.677.

[8] B. Cahyono, "Penggunaan Software Matrix Laboratory (Matlab) Dalam Pembelajaran Aljabar Linier," Phenom. J. Pendidik. MIPA, vol. 3, no. 1, pp. 45-62, 2016, doi: 10.21580/phen.2013.3.1.174.

[9] H. Dreßler, "Fuzzy information retrieval," Information-wiss. und Prax., vol. 59, no. 6-7, pp. 341-352, 2008, doi: 10.2200/s00752ed1v01y201701icr055.

\section{(c) (i) ()}

is licensed under a Creative Commons Attribution International (CC BY-SA 4.0) 